In cooperation with the Louisiana Department of Transportation and Development

\title{
Water Resources of Caddo Parish
}

\section{Introduction}

In 2005, about 72.9 million gallons per day (Mgal/d) of water were withdrawn in Caddo Parish, Louisiana (fig. 1), including about $7.70 \mathrm{Mgal} / \mathrm{d}$ from groundwater sources and 65.2 Mgal/d from surface-water sources (table 1). Public-supply use accounted for about 71 percent, and power generation accounted for about 19 percent of the total water withdrawn. Other categories of use included general irrigation, rural domestic, aquaculture, livestock, and industrial (table 2).
Water-use data collected at 5-year intervals from 1960 to 2005 indicate water withdrawals in the parish peaked in 1965 and generally decreased afterwards (fig. 2), primarily because of reduced surface-water withdrawals for power generation. From 1965 to 2005, surface-water withdrawals for power generation declined from 419 to $14.2 \mathrm{Mgal} / \mathrm{d}$.

This fact sheet summarizes basic information on the water resources of Caddo Parish, La. Information on groundwater and surface-water availability, quality, development, use, and trends is based on previously published reports listed in the references section.

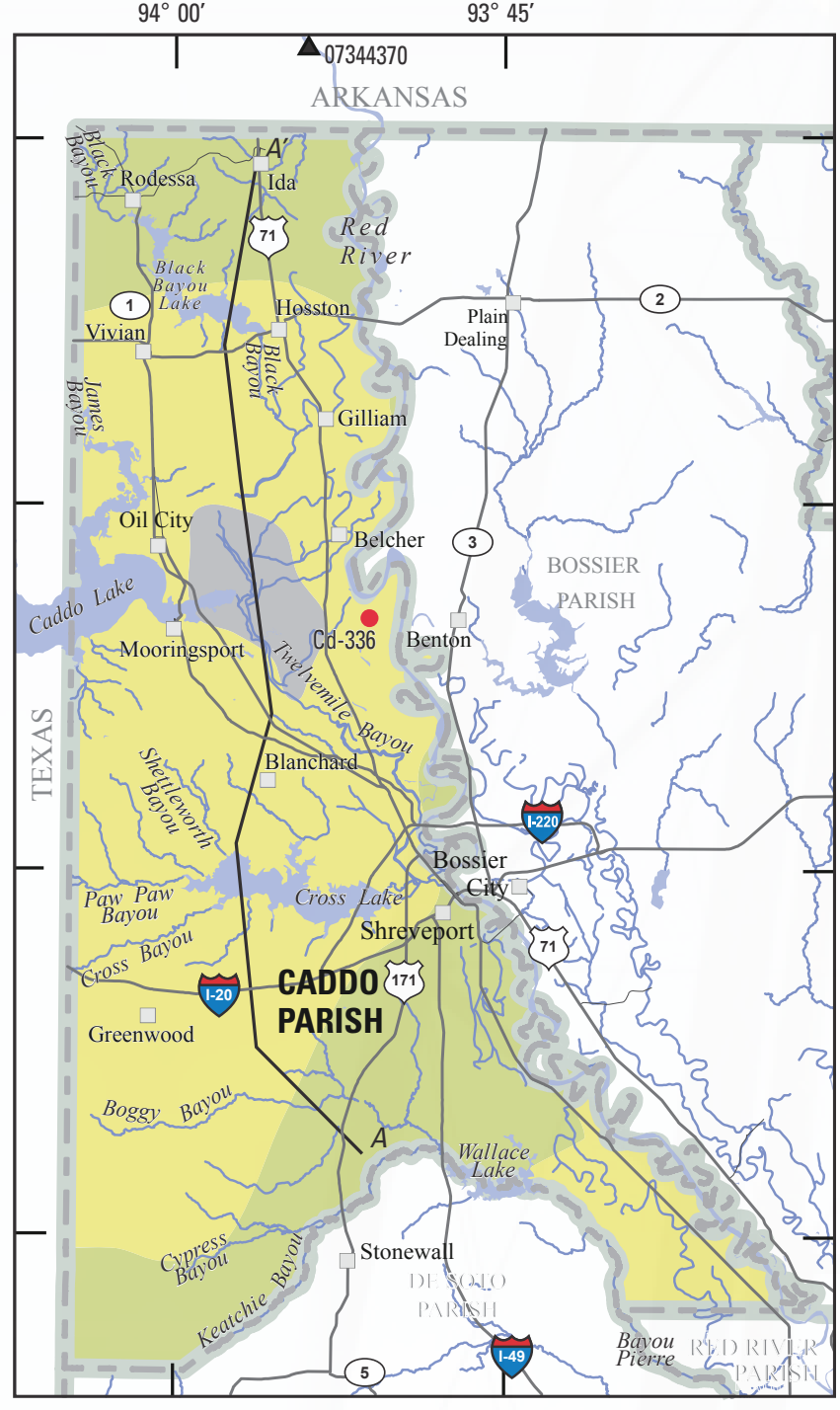

Base map modified from Official Map of Louisiana,

Louisiana Departmentof Transportation and Development, 1986
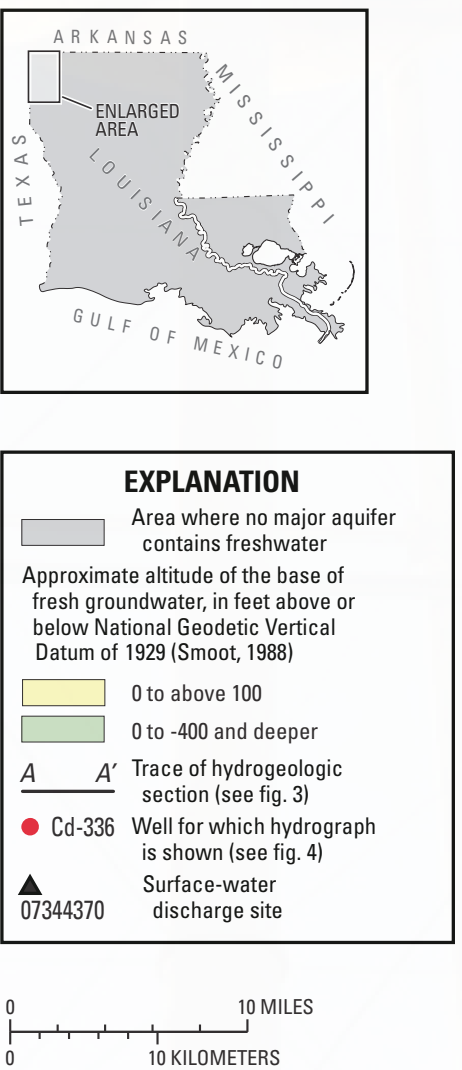

Figure 1. Location of study area, Caddo Parish, Louisiana. 
Table 1. Water withdrawals, in million gallons per day, by source in Caddo Parish, Louisiana, 2005 (modified from Sargent, 2007).

\begin{tabular}{lcc}
\hline Aquifer or surface-water body & Groundwater & Surface water \\
\hline Red River alluvial aquifer & 1.96 & - \\
Upland Terrace aquifer & 0.46 & - \\
Sparta aquifer & 0.03 & - \\
Cane River aquifer & 0.02 & - \\
Carrizo-Wilcox aquifer & 5.23 & 2.16 \\
Caddo Lake & - & 47.92 \\
Cross Lake & - & 14.12 \\
Pond (power generation) & - & 0.06 \\
Twelvemile Bayou & - & 0.89 \\
Miscellaneous streams & - & 65.15 \\
Total & 7.70 &
\end{tabular}

Table 2. Water withdrawals, in million gallons per day, by category in Caddo Parish, Louisiana, 2005 (modified from

Sargent, 2007).

\begin{tabular}{lccr}
\hline \multicolumn{1}{c}{ Category } & Groundwater & $\begin{array}{c}\text { Surface } \\
\text { water }\end{array}$ & Total \\
\hline Public supply & 1.56 & 50.04 & 51.61 \\
Industrial & 0.09 & 0.04 & 0.12 \\
Power generation & 0.00 & 14.18 & 14.18 \\
Rural domestic & 1.63 & 0.00 & 1.63 \\
Livestock & 0.10 & 0.16 & 0.27 \\
General irrigation & 2.94 & 0.73 & 3.66 \\
Aquaculture & 1.39 & 0.00 & 1.39 \\
\cline { 2 - 4 } Total & 7.70 & 65.15 & 72.85 \\
\hline
\end{tabular}

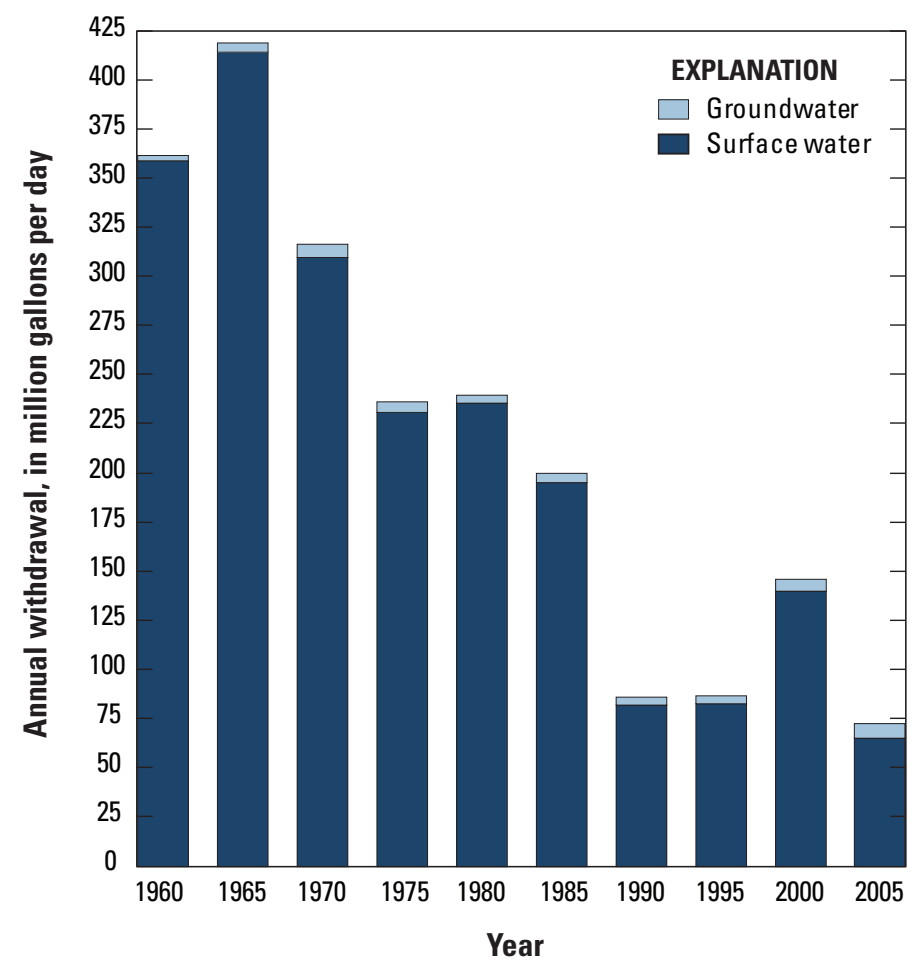

Figure 2. Water withdrawals in Caddo Parish, Louisiana, 1960-2005

\section{Groundwater Resources}

The primary groundwater resources of Caddo Parish, from near surface to deepest, include the Red River alluvial aquifer, the upland terrace aquifer, and the Carrizo-Wilcox aquifer. The Sparta aquifer and aquifers within the Cane River formation also yield freshwater in the northernmost parts of the parish (table 1) but are not considered to be major resources because of their limited extents in the parish. Fresh groundwater (water with a chloride concentration of 250 milligrams per liter [mg/L] or less) is available throughout most of the parish at depths ranging from about 100 feet (ft) above the National Vertical Datum of 1929 (NGVD 29) (sea level) near the western parish line to about 400 ft below NGVD 29 near the northern parish line (fig. 1). Fresh groundwater is not available in an area east of Caddo Lake.

Groundwater recharge and flow in Caddo Parish are affected by the Sabine uplift (an asymmetric structural dome) and faulting (fig. 3). Recharge to aquifers is from precipitation, leakage from adjacent aquifers, and seasonal input from streams. Discharge from the aquifers is by natural flow into streams, leakage into adjacent aquifers, and withdrawals from wells.

State well-registration records listed 3,741 active water wells in Caddo Parish in 2009, including 3,198 domestic, 233 publicsupply, 213 irrigation, 96 industrial, and 1 power generation wells. In 2005, groundwater withdrawals for various uses included public supply, industry, rural domestic, livestock, general irrigation, and aquaculture (table 2).

\section{The Red River Alluvial Aquifer}

The Red River alluvial aquifer borders the Red River and extends a maximum distance of about 10 miles (mi) westward into Caddo Parish from the river, which forms the eastern boundary of the parish. The aquifer is composed of sand and gravel beds within the alluvial deposits that are associated with the Red River and is hydraulically connected to the river. The alluvial deposits characteristically have a uniform sequence of clay, silt, sand, and gravel, with grain size increasing with depth. The thickness of the alluvial deposits ranges from about 25 to $100 \mathrm{ft}$.

Recharge to the alluvial aquifer is primarily from precipitation that infiltrates the overlying silty soil and from adjacent aquifers. In some areas, the aquifer is partially confined by clay deposits, and infiltration is restricted. Clayey deposits underlie the Red River alluvial aquifer and restrict downward movement of water. Water in the alluvial aquifer tends to flow by gravity downdip along the base of the aquifer towards the south or southeast and along troughs cut into the base of the aquifer, where the alluvial deposits are thicker and coarser grained.

Water levels in the alluvial aquifer fluctuate seasonally in response to precipitation, changes in the stage of adjacent rivers and streams, and withdrawal of water from the aquifer. Near the Red River, the alluvial aquifer receives recharge from the river when the river stage is higher than the water level in the aquifer; however, except for short periods when the Red River is at high stage, the alluvial aquifer generally discharges into the river. The hydrograph for well Cd-336 illustrates fluctuations in water levels in the alluvial aquifer (fig. 4).

A statistical summary of selected water-quality characteristics for freshwater from the Red River alluvial aquifer is listed in table 3 . Freshwater from the aquifer is usually very hard (greater than $180 \mathrm{mg} / \mathrm{L}$ as calcium carbonate) and generally exceeds the U.S. 


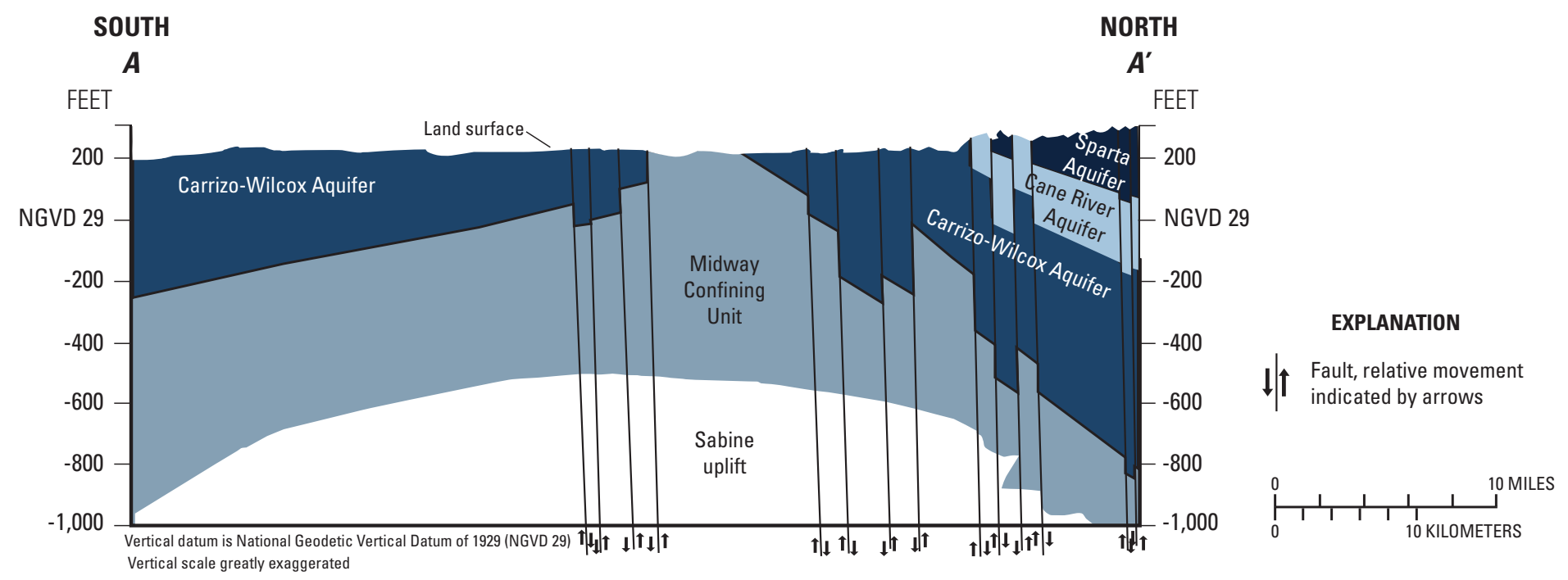

Figure 3. Generalized north-to-south hydrogeologic section through Caddo Parish, Louisiana (Rapp, 1996). Trace of section shown on figure 1.

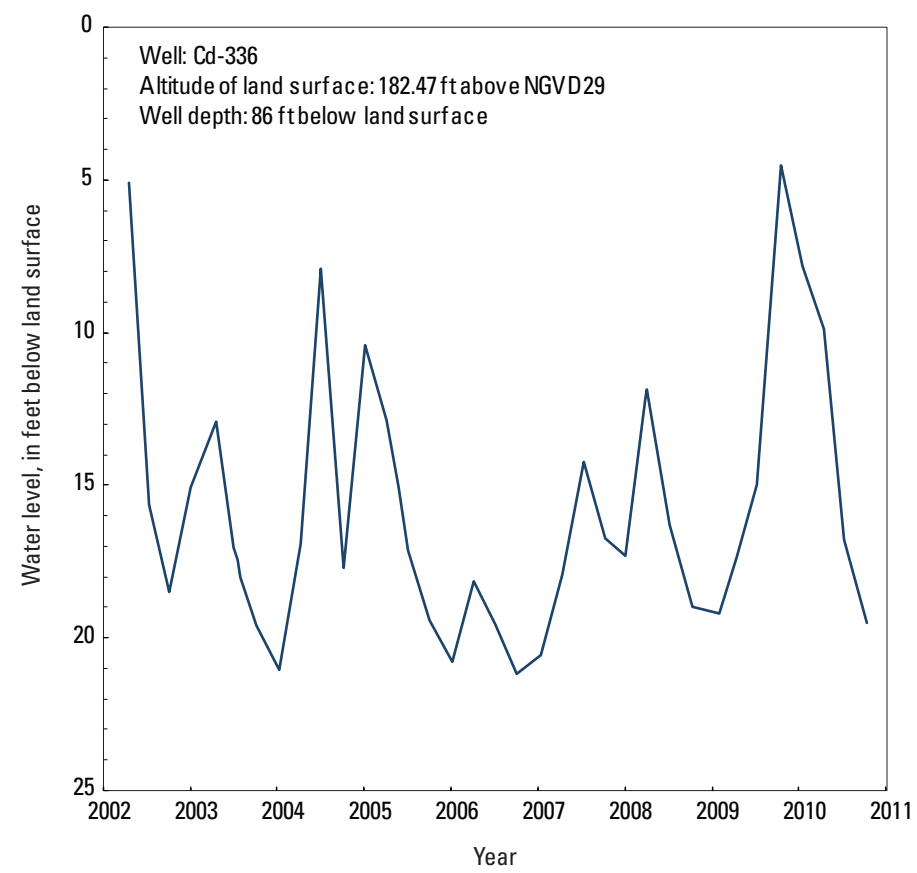

Figure 4. Water levels in well Cd-336 screened in the Red River alluvial aquifer in Caddo Parish, Louisiana (see fig. 1 for well location; U.S. Geological Survey, 2011). Land surface is measured in feet above the National Geodetic Vertical Datum of 1929 (NGVD 29).

Environmental Protection Agency's (EPA) Secondary Maximum Contaminant Levels (SMCLs) ${ }^{1}$ for drinking water for iron, manganese, and dissolved solids. Locally, water in the aquifer may be salty, with chloride concentrations exceeding the SMCL of $250 \mathrm{mg} / \mathrm{L}$.

State well-registration records listed 141 active water wells screened in the Red River alluvial aquifer in Caddo Parish in 2009, including 70 irrigation, 52 domestic, 11 industrial, and 8

\footnotetext{
${ }^{1}$ The SMCLs are nonenforceable Federal guidelines regarding cosmetic effects (such as tooth or skin discoloration) or aesthetic effects (such as taste, odor, or color) of drinking water. At high concentrations or values, health implications as well as aesthetic degradation might exist. SMCLs were established as guidelines for the States by the U.S. Environmental Protection Agency (1992).
}

public-supply wells. Depths of these wells ranged from 31 to 101 $\mathrm{ft}$ below land surface, with a median depth of $61.5 \mathrm{ft}$. Reported yields from wells screened in the alluvial aquifer in Caddo Parish have ranged from 2 to 100 gallons per minute (gal $/ \mathrm{min}$ ). In 2005, groundwater withdrawals from the Red River alluvial aquifer in Caddo Parish totaled about $1.96 \mathrm{Mgal} / \mathrm{d}$ (table 1), including 0.07 $\mathrm{Mgal} / \mathrm{d}$ for public supply, $0.03 \mathrm{Mgal} / \mathrm{d}$ for rural-domestic use, $0.03 \mathrm{Mgal} / \mathrm{d}$ for livestock, $1.27 \mathrm{Mgal} / \mathrm{d}$ for general irrigation, and $0.56 \mathrm{Mgal} / \mathrm{d}$ for aquaculture.

\section{The Upland Terrace Aquifer}

In Caddo Parish, the upland terrace aquifer is present in a discontinuous band along the western edge of the Red River alluvial valley. About 10 percent of the surface area of Caddo Parish is underlain by terrace deposits, which range in thickness by about 25-60 ft. Primary outcrop areas are located along the tributaries to Wallace Lake in southern Caddo Parish, along the northern shore of Cross Lake, along the northeastern shore of Caddo Lake, and discontinuously along Black Bayou in northwestern Caddo Parish.

Upland terrace deposits consist of clay, silt, and fine sand at the top, grading to coarse sand and gravel at the bottom. The principal source of recharge to the terrace deposits is precipitation in the outcrop area. Few water-quality data are available for wells screened in the upland terrace aquifer in Caddo Parish; however, data from four wells indicate the water is soft $(0-60 \mathrm{mg} / \mathrm{L}$ as $\left.\mathrm{CaCO}_{3}\right)$ to moderately hard $\left(60-120 \mathrm{mg} / \mathrm{L}\right.$ as $\left.\mathrm{CaCO}_{3}\right)$.

State well-registration records listed 32 active water wells screened in the upland terrace aquifer in Caddo Parish in 2009, including 17 irrigation, 13 domestic, and 2 public-supply wells. Depths of these wells ranged from 20 to $195 \mathrm{ft}$ below land surface, with a median depth of $94 \mathrm{ft}$. Reported yields from wells screened in the upland terrace aquifer in Caddo Parish have ranged 10-100 $\mathrm{gal} / \mathrm{min}$. In 2005, groundwater withdrawals from the upland terrace aquifer in Caddo Parish were about $0.46 \mathrm{Mgal} / \mathrm{d}$ (table 1), including about $0.45 \mathrm{Mgal} / \mathrm{d}$ for general irrigation and less than $0.01 \mathrm{Mgal} / \mathrm{d}$ each for public-supply and rural-domestic uses. 
Table 3. Summary of selected water-quality characteristics of freshwater in the Red River alluvial and Carrizo-Wilcox aquifers in Caddo Parish, Louisiana.

[Values are in milligrams per liter, except as noted. ${ }^{\circ} \mathrm{C}$, degrees Celsius; PCU, platinum cobalt units; $\mu \mathrm{S} / \mathrm{cm}$, microsiemens per centimeter; SU, standard units; $\mathrm{CaCO}_{3}$, calcium carbonate; $\mu \mathrm{g} / \mathrm{L}$, micrograms per liter; <, less than; NA, not applicable; SMCL, Secondary Maximum Contaminant Level established by the U.S. Environmental Protection Agency (2006)]

\begin{tabular}{|c|c|c|c|c|c|c|c|c|c|}
\hline & $\begin{array}{l}\text { Temper- } \\
\text { ature } \\
\left({ }^{\circ} \mathrm{C}\right)\end{array}$ & $\begin{array}{l}\text { Color } \\
\text { (PCU) }\end{array}$ & $\begin{array}{c}\text { Specific } \\
\text { conductance, } \\
\text { field }(\mu S / \mathrm{cm} \\
\left.\text { at } 25^{\circ} \mathrm{C}\right)\end{array}$ & $\begin{array}{l}\mathrm{pH}, \\
\text { field } \\
\text { (SU) }\end{array}$ & $\begin{array}{l}\text { Hardness } \\
\text { (as } \mathrm{CaCO}_{3} \text { ) }\end{array}$ & $\begin{array}{c}\text { Chloride, } \\
\text { filtered } \\
\text { (as CI) }\end{array}$ & $\begin{array}{c}\text { Iron, } \\
\text { filtered } \\
\text { ( } \mu \mathrm{g} / \mathrm{L} \text { as Fe) }\end{array}$ & $\begin{array}{c}\text { Manganese, } \\
\text { filtered } \\
\text { ( } \mu \mathrm{g} / \mathrm{L} \text { as } \mathrm{Mn} \text { ) }\end{array}$ & $\begin{array}{c}\text { Dissolved } \\
\text { solids, } \\
\text { filtered }\end{array}$ \\
\hline Median & 20.0 & 5 & 963 & 7.0 & 470 & 30 & 5,500 & 520 & 590 \\
\hline 10th percentile & 19.0 & $<5$ & 679 & 6.6 & 220 & 7.4 & 330 & 130 & 396 \\
\hline Number of samples & 43 & 36 & 59 & 47 & 80 & 83 & 57 & 59 & 38 \\
\hline $\begin{array}{l}\text { Percentage of samples } \\
\text { that do not exceed } \\
\text { SMCLs }\end{array}$ & NA & 94 & NA & 91 & NA & 100 & 11 & 3 & 29 \\
\hline \multicolumn{10}{|c|}{ Carrizo-Wilcox aquifer, 1940-2004 } \\
\hline Number of samples & 89 & 69 & 76 & 82 & 207 & 210 & 64 & 51 & 73 \\
\hline $\begin{array}{l}\text { Percentage of samples } \\
\text { that do not exceed } \\
\text { SMCLs }\end{array}$ & NA & 80 & NA & 89 & NA & 100 & 75 & 84 & 75 \\
\hline \multicolumn{10}{|c|}{ SMCLs } \\
\hline & NA & 15 & NA & $6.5-8.5$ & NA & 250 & 300 & 50 & 500 \\
\hline
\end{tabular}

\section{The Carrizo-Wilcox Aquifer}

The Carrizo-Wilcox aquifer is the most important aquifer in Caddo Parish because the aquifer contains freshwater throughout most of the parish. The aquifer outcrops in central and southwestern areas of the parish and dips towards both the north and south from central Caddo Parish (fig. 3). In the northern part of the parish, the aquifer is confined by clays of the Cane River Formation. The base of the Carrizo-Wilcox aquifer ranges from about $900 \mathrm{ft}$ below NGVD 29 in northern Caddo Parish to $100 \mathrm{ft}$ above NGVD 29 in central Caddo Parish and $400 \mathrm{ft}$ below NGVD 29 in southeastern Caddo Parish. In Caddo Parish, the CarrizoWilcox aquifer mainly consists of poorly interconnected, thin sand beds interbedded with clay, although some thick sands are present north of Caddo Lake. Saltwater is present in deeper sands of the aquifer throughout the parish. The aquifer is recharged by precipitation in outcrop areas and from overlying strata and primarily discharges into wells and streams. Flow of water in the aquifer is generally eastward towards the Red River. A statistical summary of selected water-quality characteristics for freshwater from the Carrizo-Wilcox aquifer is listed in table 3. Freshwater from the aquifer is soft (less than $60 \mathrm{mg} / \mathrm{L}$ as calcium carbonate) and generally does not exceed the SMCLs for color, $\mathrm{pH}$, iron, manganese, and dissolved solids. Locally, iron concentrations can greatly exceed the SMCL of $300 \mu \mathrm{g} / \mathrm{L}$ (as indicated by the $90^{\text {th }}$ percentile value of $1,100 \mathrm{mg} / \mathrm{L}$ in table 3 ).
State well-registration records listed 2,650 active water wells screened in the Carrizo-Wilcox aquifer in Caddo Parish in 2009, including 2,284 domestic, 202 public-supply, 84 irrigation, and 80 industrial wells. Depths of these wells ranged 6-826 ft below land surface, with a median depth of $200 \mathrm{ft}$. Reported yields from wells screened in the Carrizo-Wilcox aquifer in Caddo Parish have ranged 3-800 $\mathrm{gal} / \mathrm{min}$.

In 2005, groundwater withdrawals from the Carrizo-Wilcox aquifer in Caddo Parish totaled about 5.23 Mgal/d (table 1), including $1.48 \mathrm{Mgal} / \mathrm{d}$ for public supply, $0.09 \mathrm{Mgal} / \mathrm{d}$ for industry, $1.57 \mathrm{Mgal} / \mathrm{d}$ for rural-domestic use, $0.07 \mathrm{Mgal} / \mathrm{d}$ for livestock, 1.19 $\mathrm{Mgal} / \mathrm{d}$ for general irrigation, and $0.83 \mathrm{Mgal} / \mathrm{d}$ for aquaculture.

\section{Surface-Water Resources}

In 2005, 65.1 Mgal/d of surface water was withdrawn in Caddo Parish for public-supply, industrial, power-generation, livestock, and irrigation uses (table 2). Sources of withdrawal in 2005 included Cross Lake, a power-generation plant pond, Caddo Lake, miscellaneous streams, and Twelvemile Bayou (table 1). Most of the surface water withdrawn for power generation was used for cooling purposes and was returned to its source after use.

Cross Lake is the primary source of fresh surface water in Caddo Parish. In 2005, the Shreveport Water System withdrew about $47.9 \mathrm{Mgal} / \mathrm{d}$ from Cross Lake for public supply. Smaller water systems withdrew about $2.13 \mathrm{Mgal} / \mathrm{d}$ from Caddo Lake 
in 2005. Other surface-water resources in the parish include the Red River, Cypress Bayou, Black Bayou Lake, and Wallace Lake.

Cross Lake (fig. 1) was formed in 1926 when a dam was constructed across Cross Bayou to provide an adequate source of drinking water for the residents of the city of Shreveport. The elongated lake is oriented east to west and is approximately 9 miles (mi) in length with an average depth of $7.7 \mathrm{ft}$. The lake covers approximately 13.4 square miles $\left(\mathrm{mi}^{2}\right)$ in surface area and is 65,807 acre- $\mathrm{ft}$ in volume at spillway crest, which is $171.19 \mathrm{ft}$ above NGVD 29. Much of the shoreline is urbanized, particularly along the eastern and southern shores. The major types of land use surrounding Cross Lake and within its watershed are forest land, forested wetlands, residential, and to a lesser degree, cropland and pastures. The lake receives inflow from a $253-\mathrm{mi}^{2}$ watershed that includes eight major tributaries and supplemental flow through a pipeline from nearby Twelvemile Bayou. Most of the tributary inflow enters at the western end of the lake. The three largest tributaries and watershed areas are Paw Paw Bayou (82.02 mi²), Cross Bayou (62.43 $\left.\mathrm{mi}^{2}\right)$, and Shettleworth Bayou $\left(19.54 \mathrm{mi}^{2}\right)$. The lake has two distributaries, the Cross Lake Dam and Spillway and a water-treatment plant intake, both located at the eastern end of the lake.
A water-quality study of Cross Lake conducted from 1997 to 1999 indicated that water in the lake is a sodium-bicarbonate type and is soft. Fluoride, sulfate, and total dissolved solids concentrations did not exceed the EPA's SMCLs. Total (unfiltered) iron and total (unfiltered) manganese concentrations exceeded EPA SMCLs. Both iron and manganese occur naturally in the sediments of the Cross Lake watershed, and the high concentrations of total iron and total manganese in the lake water are most likely naturally occurring.

A statistical summary of selected water-quality characteristics for Cross Lake collected from 10 sites during the 1997-1999 study is presented in table 4. Based on median values, water in the lake generally does not exceed the SMCLs for $\mathrm{pH}$, chloride, or filtered iron. Dissolved oxygen is generally above $5 \mathrm{mg} / \mathrm{L}$.

Caddo Lake (fig. 1) is located in northwestern Caddo Parish and extends into Marion County, Tex. The lake has a drainage area of 2,744 $\mathrm{mi}^{2}$. Major tributaries are Big Cypress Bayou in Texas and James Bayou in Louisiana, which enter at the western and northern ends of the lake. There also are numerous smaller tributaries. Lake water level is controlled by a spillway located at the eastern end. Spillway water discharges into Willow Pass, which becomes Twelvemile Bayou. The crest elevation of the spillway is

Table 4. Summary of selected water-quality characteristics for Cross and Caddo Lakes in Caddo Parish, Louisiana, and the Red River at Coushatta, in Red River Parish, La.

[Values are in milligrams per liter, except as noted. ${ }^{\circ} \mathrm{C}$, degrees Celsius; $\mu \mathrm{S} / \mathrm{cm}$, microsiemens per centimeter; $\mathrm{SU}$, standard units; $\mu \mathrm{g} / \mathrm{L}$, micrograms per liter; CaCO , calcium carbonate; <, less than; NA, not applicable; SMCL, Secondary Maximum Contaminant Level established by the U.S. Environmental Protection Agency (2006)]

\begin{tabular}{|c|c|c|c|c|c|c|c|c|c|c|}
\hline & $\begin{array}{c}\text { Specific } \\
\text { conduc- } \\
\text { tance, } \\
\text { field }(\mu \mathrm{S} / \mathrm{cm} \\
\left.\text { at } 25^{\circ} \mathrm{C}\right) \\
\end{array}$ & $\begin{array}{l}\text { Oxygen, } \\
\text { dissolved }\end{array}$ & $\begin{array}{l}\text { pH, } \\
\text { field } \\
\text { (SU) }\end{array}$ & $\begin{array}{l}\text { Hard- } \\
\text { ness } \\
\text { (as } \\
\mathrm{CaCO}_{3} \text { ) } \\
\end{array}$ & $\begin{array}{c}\text { Calcium, } \\
\text { filtered } \\
\text { (as Ca) }\end{array}$ & $\begin{array}{l}\text { Mag- } \\
\text { nesium, } \\
\text { filtered } \\
\text { (as Mg) }\end{array}$ & $\begin{array}{l}\text { Sodium, } \\
\text { filtered } \\
\text { (as Na) }\end{array}$ & $\begin{array}{c}\text { Chloride, } \\
\text { filtered } \\
\text { (as CI) }\end{array}$ & $\begin{array}{l}\text { Sulfate, } \\
\text { filtered } \\
\text { (as } \mathrm{SO}_{4} \text { ) }\end{array}$ & $\begin{array}{c}\text { Iron, } \\
\text { filtered, } \\
\text { ( } \mu \mathrm{g} / \mathrm{L} \\
\text { as Fe) }\end{array}$ \\
\hline \multicolumn{11}{|c|}{ Cross Lake, 1997-1999 } \\
\hline Median & 168 & 8.2 & 7.0 & 37 & 8.5 & 3.8 & 13 & 17 & 13 & 120 \\
\hline 10th percentile & 102 & 4.3 & 6.4 & 23 & 5.3 & 2.3 & 8.2 & 11 & 7 & 8 \\
\hline 90th percentile & 290 & 10.4 & 8.8 & 71 & 17 & 7.1 & 29 & 42 & 28 & 240 \\
\hline Number of samples & 128 & 129 & 129 & 75 & 75 & 75 & 74 & 75 & 72 & 41 \\
\hline $\begin{array}{l}\text { Percentage of samples that } \\
\text { do not exceed SMCLs }\end{array}$ & NA & NA & 74 & NA & NA & NA & NA & 100 & 100 & 95 \\
\hline \multicolumn{11}{|c|}{ Caddo Lake, 1973-1992 } \\
\hline Median & 105 & 8.8 & 6.7 & 22 & 5.1 & 2.3 & 9.3 & 13 & 11 & 140 \\
\hline 10th percentile & 94 & 6.9 & 6.2 & 18 & 4.1 & 2 & 8.2 & 11 & 7.3 & 20 \\
\hline 90th percentile & 122 & 10.5 & 7.2 & 27 & 6.6 & 2.5 & 11 & 17 & 15 & 370 \\
\hline Number of samples & 32 & 32 & 32 & 31 & 31 & 31 & 30 & 31 & 32 & 29 \\
\hline $\begin{array}{l}\text { Percentage of samples that } \\
\text { do not exceed SMCLs }\end{array}$ & NA & NA & 84 & NA & NA & NA & NA & 100 & 100 & 72 \\
\hline
\end{tabular}

Red River at Coushatta, 1995-2009'

$\begin{array}{lrrrrrrrrrr}\text { Median } & 504 & 8.1 & 7.8 & 140 & 37 & 10 & 49 & 65 & 64 & 20 \\ \text { 10th percentile } & 232 & 5.6 & 7.3 & 67 & 20 & 4.5 & 18 & 21 & 23 & <6 \\ \text { 90th percentile } & 1,200 & 11.8 & 8.2 & 290 & 73 & 23 & 130 & 190 & 160 & 90 \\ \text { Number of samples } & 170 & 156 & 172 & 167 & 167 & 169 & 168 & 170 & 170 & 66 \\ \begin{array}{l}\text { Percentage of samples that } \\ \quad \text { do not exceed SMCLs }\end{array} & \text { NA } & \text { NA } & 93 & \text { NA } & \text { NA } & \text { NA } & \text { NA } & 99 & 100 & 100\end{array}$

SMCLs

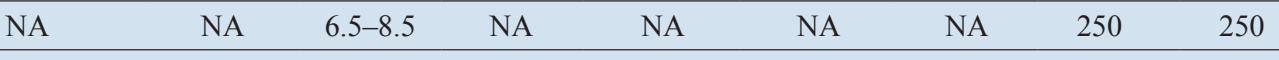

${ }^{\text {'Station number }} 07350500$ (U.S. Geological Survey, 2010b; specific data at http://nwis.waterdata.usgs.gov/la/nwis/qwdata/?site_no=07350500\&amp). 
$168.5 \mathrm{ft}$ above NGVD 29, and the maximum design discharge of the spillway is 36,000 cubic feet per second $\left(\mathrm{ft}^{3} / \mathrm{s}\right)$. Caddo Lake is a wide, shallow lake, and shallow areas of the lake are densely vegetated. The lake has a surface area of about 26 $\mathrm{mi}^{2}$, an average depth of $4.6 \mathrm{ft}$, and a depth of $4.6 \mathrm{ft}$ or greater in more than 50 percent of the lake area. Greatest depths are located in the eastern part of the lake; east of the bridge on State Highway 538 (near Moorsingsport) the water depth is approximately $27 \mathrm{ft}$. Thirty-three water samples collected from Caddo Lake at the Highway 1 bridge near Mooringsport or at the spillway during 1973-1992 indicate that water in Caddo Lake is generally soft $\left(0-60 \mathrm{mg} / \mathrm{L}\right.$ as $\left.\mathrm{CaCO}_{3}\right)$ and does not exceed EPA's SMCLs for $\mathrm{pH}$ and for chloride and sulfate concentrations. Concentrations of filtered iron exceeded the SMCL of $250 \mathrm{mg} / \mathrm{L}$ in 8 of 29 samples (table 4).

Although there were no reported withdrawals of water from the Red River in Caddo Parish in 2005, the river is a large potential source of freshwater. The average discharge of the Red River was 19,480 $\mathrm{ft}^{3} / \mathrm{s}$ for water years $1998-2008$ at a site about 4.5 mi upstream from Caddo Parish at Spring Bank, Arkansas (station number 07344370). The highest mean daily discharge of the Red River during this 10-year period was $138,000 \mathrm{ft}^{3} / \mathrm{s}$ on March 14, 2001, and the lowest was 1,100 $\mathrm{ft}^{3} / \mathrm{s}$ on October 11, 2006. Water samples collected during 1995-2009 in the Red River at Coushatta, La., located about 17 mi south of Caddo Parish in Red River Parish, indicate that the water is generally hard $\left(121-180 \mathrm{mg} / \mathrm{L}\right.$ as $\left.\mathrm{CaCO}_{3}\right)$. The $\mathrm{pH}$ and concentrations of chloride, sulfate, and iron generally meet the EPA's SMCLs (table 4).

\section{Selected References}

McGee, B.D., 2004, Water-quality and bottom-material characteristics of Cross Lake, Caddo Parish, Louisiana, 1997-99: U.S. Geological Survey Water-Resources Investigations Report 03-4135, 101 p.

Page, L.V., and May, H.G., 1964, Water Resources of Bossier and Caddo Parishes, Louisiana: Department of Conservation, Louisiana Geological Survey, and Louisiana Department of Public Works Water Resources Bulletin no. 5, 105 p.

Rapp, T.R., 1996, Ground-water resources of Caddo Parish, Louisiana, 1992: Louisiana Department of Transportation and Development Water Resources Technical Report no. 58, 89 p.

Sargent, B.P., 2007, Water use in Louisiana, 2005: Louisiana Department of Transportation and Development Water Resources Special Report no. 16, $133 \mathrm{p}$.

Smoot, C.W., 1988, Louisiana hydrologic atlas map no. 3: Altitude of the base of freshwater in Louisiana: U.S. Geological Survey WaterResources Investigations Report 86-4314, 1 sheet.

U.S. Environmental Protection Agency, 1992, Secondary Drinking Water Regulations - guidance for nuisance chemicals: U.S. Environmental Protection Agency publication EPA 810/K-92-001, 4 p., accessed July 29, 2009, at http:/www.epa.gov/safewater/ consumer/2ndstandards.html.

U.S. Environmental Protection Agency, 2006, 2006 Edition of the drinking water standards and health advisories: Washington D.C., U.S. Environmental Protection Agency, Office of Water, 12 p.

U.S. Geological Survey, 2010a, Water Quality Samples for Louisiana [data for USGS 07350500 Red R @ Coushatta, La.]: National Water Quality Information System Web Interface, accessed November 5, 2009, at http://nwis.waterdata.usgs.gov/la/nwis/qwdata/?site no $=07350500 \&$ amp.
U.S. Geological Survey, 2010b, Annual water-data report 2008 [for gage 07344370 Red River at Spring Bank, AR]: USGS Water Resources of the United States, Publications-Annual Water Data Reports, accessed November 6, 2009, at http://wdr.water.usgs.gov/ wy2008/pdfs/07344370.2008.pdf.

U.S. Geological Survey, 2011, Ground-water levels for Louisiana [data for USGS 324207093484801 Cd- 336]: National Water Quality Information System Web Interface, accessed January 12, 2011, at http://nwis.waterdata.usgs.gov/la/nwis/gwlevel/?site no $=324207093484801 \&$ amp.

\section{By Lawrence B. Prakken and Jason M. Griffith}

\section{For additional information, contact:}

Director, USGS Louisiana Water Science Center

3535 S. Sherwood Forest Blvd., Suite 120

Baton Rouge, LA 70816

E-mail: dc_la@usgs.gov

Fax: (225) 298-5490

Telephone: (225) 298-5481

Home Page: http://la.water.usgs.gov
This fact sheet was published by the U.S. Geological Survey, in cooperation with the Louisiana Department of Transportation and Development (DOTD). Thanks are given to Zahir "Bo" Bolourchi, Director, Water Resources Programs, Louisiana Department of Transportation and Development, who contributed to the content and design of the fact sheet. 